\section{Andreia Morales Cascaes', \\ Renata Moraes Bielemann" \\ Valerie Lyn Clark" \\ Aluísio J D Barros"}

\title{
Effectiveness of motivational interviewing at improving oral health: a systematic review
}

\section{Efetividade da entrevista motivacional na melhoria da saúde bucal: revisão sistemática}

\begin{abstract}
OBJECTIVE: To analyze the effectiveness of motivational interviewing (MI) at improving oral health behaviors (oral hygiene habits, sugar consumption, dental services utilization or use of fluoride) and dental clinical outcomes (dental plaque, dental caries and periodontal status).

METHODS: A systematic search of PubMed, LILACS, SciELO, PsyINFO, Cochrane and Google Scholar bibliographic databases was conducted looking for intervention studies that investigated MI as the main approach to improving the oral health outcomes investigated.
\end{abstract}

RESULTS: Of the 78 articles found, ten met the inclusion criteria, all based on randomized controlled trials. Most studies $(\mathrm{n}=8)$ assessed multiple outcomes. Five interventions assessed the impact of MI on oral health behaviors and nine on clinical outcomes (three on dental caries, six on dental plaque, four on gingivitis and three on periodontal pockets). Better quality of evidence was provided by studies that investigated dental caries, which also had the largest population samples. The evidence of the effect of MI on improving oral health outcomes is conflicting. Four studies reported positive effects of MI on oral health outcomes whereas another four showed null effect. In two interventions, the actual difference between groups was not reported or able to be recalculated.

Departamento de Odontologia Social e Preventiva. Faculdade de Odontologia. Universidade Federal de Pelotas. Pelotas, RS, Brasil

\footnotetext{
" Programa de Pós-Graduação em Epidemiologia. Universidade Federal de Pelotas. Pelotas, RS, Brasil
}

\author{
Correspondence: \\ Andreia Morales Cascaes \\ Faculdade de Odontologia \\ Departamento de Odontologia Social e \\ Preventiva \\ Universidade Federal de Pelotas \\ Rua Gonçalves Chaves, 457 \\ 96015-560 Pelotas, RS, Brasil \\ E-mail: andreiacascaes@hotmail.com

CONCLUSIONS: We found inconclusive effectiveness for most oral health outcomes. We need more and better designed and reported interventions to fully assess the impact of MI on oral health and understand the appropriate dosage for the counseling interventions.

DESCRIPTORS: Motivational Interviewing, utilization. Health Behavior. Patient Acceptance of Health Care. Health Promotion, methods. Oral Health; Review. 


\section{RESUMO}

OBJETIVO: Analisar a efetividade da entrevista motivacional na melhoria dos comportamentos em saúde bucal (higiene bucal, consumo de açúcar, uso de serviços odontológicos e uso de fluoretos) e dos desfechos clínicos (placa dentária, cárie e condições periodontais).

MÉTODOS: Revisão sistemática da literatura com busca nas bases de dados PubMed, Web of Science, Lilacs, SciELO, PsyINFO, Cochrane e Google Scholar. Foram incluídos estudos que investigaram a entrevista motivacional como a principal abordagem para melhorar os desfechos em saúde bucal investigados.

RESULTADOS: De 78 estudos localizados, dez foram incluídos, todos randomizados e controlados; a maioria $(\mathrm{n}=8)$ avaliou múltiplos desfechos. Cinco intervenções acessaram o impacto da entrevista motivacional nos comportamentos em saúde bucal e nove em desfechos clínicos (três em cárie, seis em placa dentária, quatro em gengivite e três em bolsas periodontais). A melhor qualidade de evidência foi encontrada nos estudos que investigaram cárie, os quais também possuíam as maiores amostras populacionais. A evidência do efeito da entrevista motivacional na melhoria da saúde bucal foi conflituosa. Quatro estudos reportaram efeitos positivos, enquanto outros quatro mostraram efeito nulo. A real diferença entre os grupos não foi apresentada ou possível de recalcular em duas intervenções.

CONCLUSÕES: Encontramos resultados inconclusivos para a maioria dos desfechos. São necessárias mais intervenções com metodologias mais apropriadas que avaliem amplamente o impacto da entrevista motivacional na saúde bucal, além de conhecer a dosagem adequada para as intervenções.

DESCRITORES: Entrevista Motivacional, utilização. Comportamentos Saudáveis. Aceitação pelo Paciente de Cuidados de Saúde. Promoção da Saúde, métodos. Saúde Bucal. Revisão.

\section{INTRODUCTION}

Most chronic dental problems are preventable by adopting effective preventive behaviors, such as regular oral hygiene (brushing teeth with fluoride toothpaste), $)^{2,11}$ reduction of consumption of sugar ${ }^{36}$ and cessation of tobacco smoking. ${ }^{34}$ While some population groups are free or have low rates of dental diseases, others, especially the poor, suffer from a higher incidence, which indicates the need for preventive interventions. ${ }^{29}$

Meta-analyses and systematic reviews of oral health interventions point to the absence or ineffectiveness of educational interventions for the prevention of dental disease. ${ }^{7,21,39,41,42}$ Most are traditional interventions, with a curative-restorative approach through lectures and the distribution of pamphlets. Other strategies for mass communication do not sufficiently consider the sociocultural context or behavioral determinants. ${ }^{42}$

Transforming knowledge into actions which are beneficial to the population and affordable and creating opportunities and conditions that enable individuals and communities to enjoy good oral health is the great challenge. ${ }^{30,42}$ There has been a rising number of interventions that aim to change behaviors using approaches from Psychology. ${ }^{3}$ One popular approach in recent years that is proving to be a promising prospect in creating lasting change and improvement in health interventions is a technique called motivational interviewing (MI). ${ }^{8} \mathrm{MI}$ was defined by Miller $\&$ Rollnick $^{25}$ (2002) as a technique based on evidence, centered on the individual, and individually-tailored. The focus of the approach is to prepare the individual for change by promoting and facilitating resolution of the ambivalence of individual decisions about how to change and proceed. ${ }^{25} \mathrm{MI}$ can contribute to constructing new knowledge and to reducing the individual's resistance to change, thus, helping to overcome difficult situations. ${ }^{31}$ 
It is considered to be a refined form of the guideline and involves three styles of communication: direct, guide, and monitor; plus three skills: ask, inform, and listen. ${ }^{31} \mathrm{MI}$ is described as collaborative, evocative and with respect for individual autonomy. It is not a technique to get people to do what they do not want, but rather to evoke their motivations to make changes in behaviors for their health. ${ }^{26}$

The effectiveness of the MI approach for more lasting behavior change with consequent improvements in health outcomes has been documented in several systematic reviews related to alcohol use, ${ }^{5,30}$ smoking, ${ }^{11,12}$ eating disorders, ${ }^{23}$ as well as the promotion of physical activity and healthy eating habits. ${ }^{24}$

There has been little investigation in the area of oral health and the evidence is not clear. This theory-based approach to health behavior modification, already successfully applied in other fields of medicine, might be a good alternative to conventional oral health promotion. However, no systematic review with recent studies involving rigorous evaluation of oral health on this subject is available. A review from 2009 on the effectiveness of MI in health promotion ${ }^{24}$ just touched the issue of oral health by revising four articles with oral health outcomes. The authors concluded that the approach seems promising for improving oral health. These studies bring limited evidence given they were derived from two different empirical studies with considerably distinct populations. The publications suggest that MI might reduce dental care avoidance in adolescents (a pilot scale study), ${ }^{37}$ and dental caries in young children, by targeting their mothers, in a 2-year intervention. ${ }^{15,43,44}$ The evidence on effectiveness of MI at improving oral health is scarce, which invites further work.

This study aimed to analyze the effectiveness of motivational interviewing in changing oral health behaviors and preventing dental clinical problems.

\section{METHODS}

Systematic review of the literature conducted in PubMed, LILACS, SciELO, PsycINFO, Cochrane Database of Systematic Reviews and Google Scholar in April 2013 and without date limits or language restrictions. The references of all reviewed articles were also scanned for potential, additional articles.

The search used the expression: (((Motivational interviewing or motivational interview))) AND (()((()((Oral health or dental health)) OR (Oral health behaviors or oral health behavioral change)) OR (Dental hygiene or oral hygiene)) OR ((Sweet foods or sweet drinks or sweet beverages) and (consumption or intake))) OR (Dental caries or tooth decay or early childhood dental caries)) OR Dental plaque) OR (Gingival bleeding or bleeding on probing)) OR (Periodontal disease or periodontal pocket or periodontal probing depth or clinical attachment loss)).

The inclusion criteria were intervention studies that: utilized MI as the main approach to improve oral health in at least one intervention group; included a control group; evaluated as outcome changes in one of the four oral health behaviors: oral hygiene habits, sugar consumption, dental service utilization or use of fluoride; or clinical oral health outcomes: dental plaque, dental caries or periodontal conditions (gingival bleeding or periodontal disease).

All types of studies that aimed to teach the MI approach to professionals or students or included preventive components in one or more intervention groups other than MI or traditional education (e.g., professional treatment, professional application of topical fluoride gel, varnish or mouthwash or supervised tooth-brushing) were excluded.

A database with the search results was generated using the EndNote 3.1 tool, excluding duplicate references, totaling 78 articles. The selection of articles to be included was performed independently by two of the authors. The decision was based on a third reviewer in case of disagreement. Each reviewer selected the titles and abstracts for articles of interest. Then, we proceeded to search the full text.

The evaluation of the quality of evidence was also performed independently by two authors. The disagreements were discussed between these two authors and the consensus technique was applied to the final decision. The quality of studies was assessed with the instrument proposed by Downs \& Black ${ }^{12}$ (1998) that originally consists of 27 questions on reporting, external validity, internal validity (bias and confounding), and statistical power, yielding a score varying from zero to 28 . We excluded the question about the attempt to blind subjects to exposure as it does not apply to the kind of intervention studied here. The maximum score was 27 in our case. The quality of evidence of the studies were categorized as being excellent (24 to 27), good (20 to 23), fair (15 to 19$)$, poor or limited (14 or less). We did not exclude any study on the basis of quality of evidence, given that we wanted to assess all studies on MI and oral health.

\section{RESULTS}

Of the 104 references initially identified, 26 were excluded due to duplication. From 78 references, 17 papers selected from the titles or abstracts, seven were excluded after reading the full text: two articles were excluded because the behavioral intervention used was not $\mathrm{MI} ;{ }^{28,35}$ one was just a commentary, ${ }^{45}$ one did not measure any outcome studied in this review; ${ }^{37}$ and three had been superseded by more comprehensive analyses published later ${ }^{15,19-20}$ (Figure 1). 


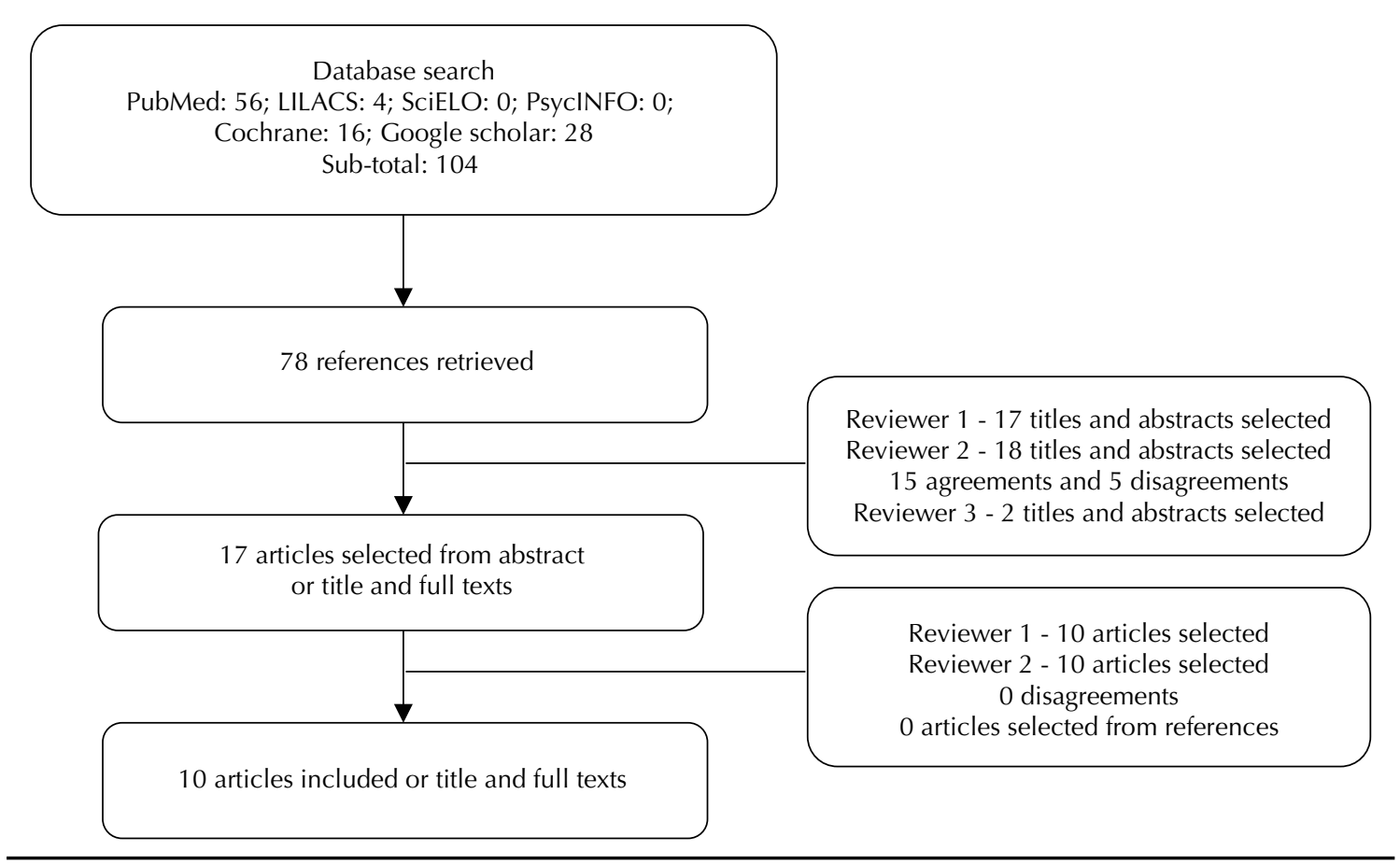

Figure 1. Flow diagram of study selection.

\section{Description of studies}

All 10 papers reviewed were based on randomized controlled trials and were performed in high income countries in North America and Europe. The majority of studies investigated adults with a mean age of 50 years $(n=6)$, mostly subjects attending university programs or dental clinics. ${ }^{1,6,14,22,40}$ The other four interventions were performed with parents of young children up to five years old in their communities, of immigrants, ${ }^{15}$ indigenous ${ }^{16}$ and low-income populations ${ }^{13,18}$ (Table 1).

Several limitations in the randomization process were identified. Some studies needed to attempt to control for confounding variables not sufficiently dealt with by the randomization process. These problems, allied with a variety of outcomes, both clinical and non-clinical, and different ways of measuring them, make the drawing of a clear conclusion difficult. The pooling of the results was deemed impossible given the circumstances.

The MI interventions varied in duration (15 to 90 minutes) and number of sessions (one to seven), as well as by the addition or not of the traditional approach, as available, to the control group (Table 1). Almost all studies included a control group that received traditional educational intervention, citing ethical concerns as the reason. Most often they involved presenting oral hygiene guidelines, video programs or delivering leaflets. One study did not provide any oral health education to the control group because the district health department provides a fluoride varnish program in the public school system twice a year. ${ }^{13}$ Pamphlets were available for the control mothers to take home if desired and questions were answered, if posed, during children's regular dental visits. ${ }^{13}$

Five studies used a trained counselor with extensive experience in $\mathrm{MI},{ }^{1,6,13,18}$ two interventions were delivered by community members that received MI training, ${ }^{15,16}$ one was performed by two dentists and another two studies did not report who delivered the intervention sessions. ${ }^{19,22}$ Participants in most studies received individualized $\mathrm{MI}$ intervention, during dental visits or wellness child visits. ${ }^{1,6,13,14,16,22}$ In one publication, it was not clear if the video sessions were performed in groups or individualized. ${ }^{18}$ Six of the seven MI sessions were conducted by telephone in Harisson et $\mathrm{a}^{15}$ (2007) intervention and Freudenthal \& Bowden ${ }^{13}$ (2010) performed follow-up sessions by telephone. Five studies audio recorded the sessions to assess the counselor's fidelity in providing MI. ${ }^{6,15,18,40}$

\section{Quality of evidence}

The total mean score was 19.3 points $(\mathrm{SD}=2.6)$, according to Downs \& Black $^{12}$ (1998). The minimum score, 14 , was assigned to the Freudenthal $\&$ Bowden $^{13}$ study (2010) and the maximum, 22, to the studies of Harisson et $\mathrm{a}^{15}$ (2007), Ismail et a ${ }^{18}$ (2011) and Brand et $\mathrm{al}^{6}$ (2012) (Table 2).

Five publications scored between 20 and 23, classified as being good evidence. ${ }^{6,14,15,18,40}$ Four articles scored $<20$, considered fair quality of evidence, ${ }^{16,19,22}$ and one showed limited quality of evidence. ${ }^{13}$ 


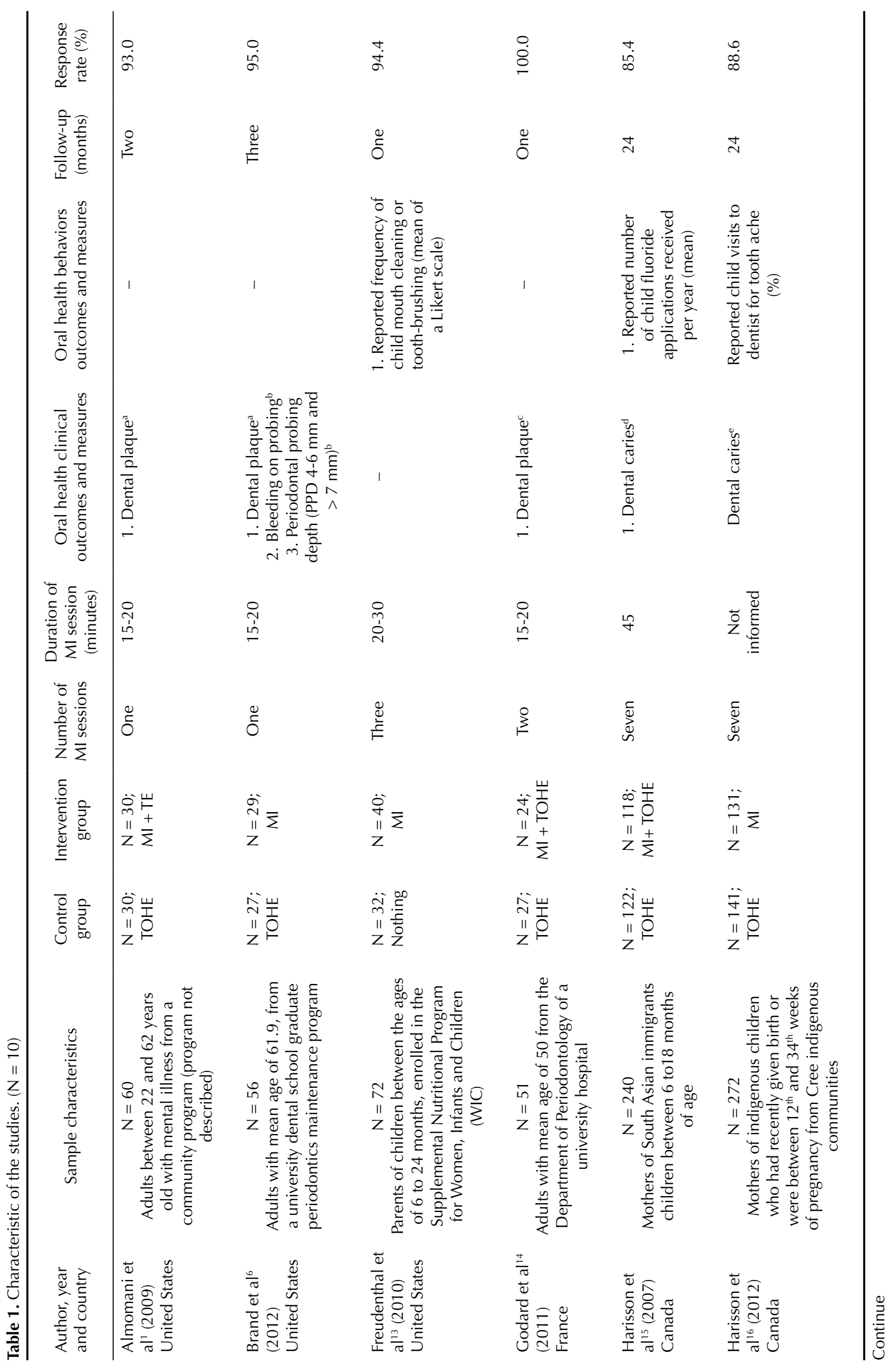




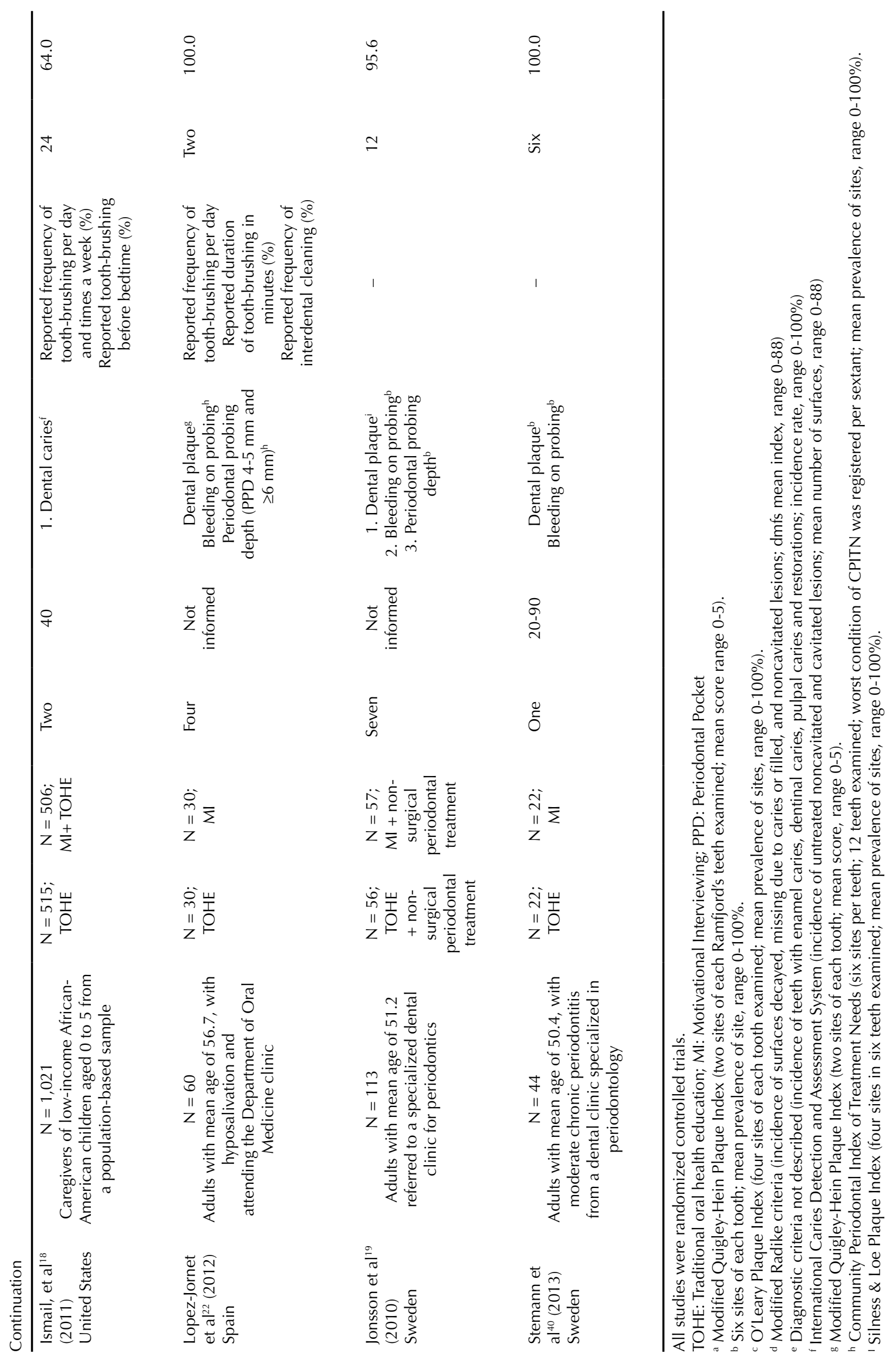


Table 2. Evaluation criteria adapted from Downs \& Black (1998).

\begin{tabular}{|c|c|c|c|c|c|c|}
\hline Studies & $\begin{array}{l}\text { Reporting } \\
{[0 \text { to } 10]}\end{array}$ & $\begin{array}{l}\text { External } \\
\text { validity } \\
\text { [0 to 3] }\end{array}$ & $\begin{array}{c}\text { Bias }^{\mathrm{a}} \\
{[0 \text { to } 6]}\end{array}$ & $\begin{array}{c}\text { Confounding } \\
{[0 \text { to } 6]}\end{array}$ & $\begin{array}{l}\text { Power } \\
\text { [0 to 1] }\end{array}$ & $\begin{array}{c}\text { Overall score } \\
\text { [0 to 26] }\end{array}$ \\
\hline Brand et $\mathrm{al}^{6}(2012)$ & 10 & 0 & 6 & 5 & 1 & 22 \\
\hline Harisson et al ${ }^{15}$ (2007) & 10 & 2 & 6 & 4 & 0 & 22 \\
\hline Ismail et $\mathrm{al}^{18}(2011)$ & 9 & 2 & 5 & 5 & 1 & 22 \\
\hline Godard et al ${ }^{14}(2011)$ & 10 & 1 & 6 & 4 & 0 & 21 \\
\hline Stemman et $\mathrm{al}^{40}(2012)$ & 8 & 1 & 5 & 6 & 0 & 20 \\
\hline Jonsson et al ${ }^{19}(2010)$ & 9 & 1 & 5 & 4 & 0 & 19 \\
\hline Almomani et al $^{1}$ (2009) & 8 & 1 & 4 & 4 & 1 & 18 \\
\hline Lopez-Jornet et al ${ }^{22}$ (2013) & 7 & 1 & 5 & 5 & 0 & 18 \\
\hline Harisson et al ${ }^{16}$ (2012) & 5 & 0 & 6 & 5 & 1 & 17 \\
\hline Freudenthal et al ${ }^{13}$ (2010) & 5 & 2 & 4 & 3 & 0 & 14 \\
\hline Mean $(\mathrm{SD})$ Total $(\mathrm{N}=10)$ & $8.1(1.9)$ & $1.1(0.7)$ & $5.2(0.8)$ & $4.5(0.8)$ & $0.4(0.5)$ & $19.3(2.6)$ \\
\hline
\end{tabular}

${ }^{\text {a }}$ Question 14 was excluded

Overall score of outcomes investigated varied from worse to better evidence: 18.6 (SD 3.4; min 14, $\max$ 22), 19.7 (SD 1.6; $\min 18, \max 22$ ), 19.7 (SD 2.1; min 18 , $\max 22), 19.8$ (SD 1.7; $\min 18, \max 22$ ) and 20.3 (SD 2.9, min 17, $\max 22$ ) for oral health behaviors, dental plaque, periodontal pocket, gingival bleeding and dental caries, respectively. The main problems identified were: lack of representative samples $(n=7)$; inadequate analysis due to the absence of comparison between groups, not reporting actual p-value and intervention efficacy measures $(n=7)$; lack of adjustment for confounding $(\mathrm{n}=6)$, not accounting for losses in the analysis $(\mathrm{n}=4)$; no a priori sample size calculation, resulting in convenience samples and studies with low power to detect differences $(n=4)$; the lack of blinding of outcomes $(\mathrm{n}=3)$; the lack of blinding and detailing aspects of randomization $(n=3)$.

\section{Effectiveness of MI}

We analyzed the effectiveness of MI in the ten different interventions. Five studies assessed the impact of MI on oral health behaviors outcomes and nine on dental clinical outcomes (three on dental caries, six on dental plaque, four on gingivitis and three on periodontal pockets). We were able to calculate and present the actual p-value of some studies that did not compare differences between control and intervention groups. Other publications did not provide enough information to calculate actual p-values not presented in the articles (Table 3).

\section{Oral health behaviors}

The evidence for the effectiveness of motivational interviewing on improving oral health behaviors was conflicting and could not be established with confidence. The use of MI significantly improved the number of fluoride varnish applications in the parents who were recommended to take their child to the dentist to apply fluoride. ${ }^{15}$ The most investigated behavior was oral hygiene, presented in three studies ${ }^{13,18,22}$ and one found improvements of reported oral hygiene in the intervention group compared to control. ${ }^{22}$ No study assessed the impact of MI on changing sugar consumption and no effect was found that investigated improvements for dental service utilization. ${ }^{16}$

\section{Dental caries}

Two interventions reported no significant effect on reducing dental caries ${ }^{16,18}$ and one has found a positive effect, with an estimated relative risk (RR) of 0.44 , i.e., the intervention was able to prevent $56.0 \%$ of dental caries. ${ }^{15}$ Although the study of Harisson et al (2012) did not find a significant difference between groups $(\mathrm{p}=0.17)$, relative risk showed preventive direction $(\mathrm{RR}=0.8695 \% \mathrm{CI} 0.66 ; 1.07)$.

\section{Dental plaque}

Evidence on dental plaque reduction was also unable to be established. Two studies with good evidence quality assessment showed no significant effect. Another two with good ${ }^{14}$ and fair ${ }^{19}$ quality of evidence showed relevant magnitude of protection in MI groups compared to controls: $39.0 \%{ }^{14}$ and $77.0 \%{ }^{19}$ of reduction in the percentage of affected sites. Actual p-value was not present or able to be recalculated in another two interventions. ${ }^{1,22}$ However, Almomani et al ${ }^{1}$ (2009) presented a reduction of $47.0 \%$ of plaque in the intervention group compared to $24.0 \%$ in the control. 
Table 3. Main results about the effectiveness of motivational interviewing according to the outcomes.

\begin{tabular}{|c|c|c|c|c|}
\hline \multirow{2}{*}{ Outcomes } & \multirow{2}{*}{ Reference } & \multicolumn{2}{|c|}{ Summary findings } & \multirow{2}{*}{ p-value } \\
\hline & & Control group & Intervention group & \\
\hline \multicolumn{5}{|c|}{ Oral health behaviors } \\
\hline Dental utilization & $\begin{array}{l}\text { Harisson et al }{ }^{16} \\
\quad(2012)\end{array}$ & $\begin{array}{l}\text { B: } 35.5 \%(N=39) \\
F: 15.4 \%(N=17)\end{array}$ & $\begin{array}{l}\text { B: } 50.0 \%(N=65) \\
F: 24.4 \%(N=32)\end{array}$ & $0.085^{a}$ \\
\hline Sugar consumption & - & - & - & - \\
\hline \multirow[t]{3}{*}{ Oral hygiene } & $\begin{array}{l}\text { Freudenthal et al }{ }^{13} \\
\qquad(2010)\end{array}$ & $\begin{array}{l}\text { B: mean } 3.2(\mathrm{SD} \mathrm{NI}) \\
\text { F: mean } 3.3(\mathrm{SD} \mathrm{NI})\end{array}$ & $\begin{array}{l}\text { B: mean } 2.8(\mathrm{SD} \mathrm{NI}) \\
\text { F: mean } 3.7(\mathrm{SD} \mathrm{NI})\end{array}$ & $\mathrm{NI}$ \\
\hline & Ismail et al ${ }^{18}(2011)$ & $\begin{array}{c}\text { Brushing } 2 \times \text { per day: } \\
\text { B: } 47.3 \%(\mathrm{~N}=142) \\
\text { F: } \mathrm{NI} \\
\text { Brushing } 7 \text { days per week: } \\
\text { B: } 77.3 \%(\mathrm{~N}=232) \\
\text { F: } \mathrm{NI} \\
\text { Brushing } 7 \text { days a week at } \\
\text { bedtime: } \\
\text { B: } 25.3 \%(\mathrm{~N}=76) \\
\mathrm{F}: \mathrm{NI}\end{array}$ & $\begin{array}{c}\text { Brushing } 2 x \text { per day: } \\
\text { B: } 56.1 \%(\mathrm{~N}=168) \\
\mathrm{F}: \mathrm{NI} \\
\text { Brushing } 7 \text { days per week: } \\
\text { B: } 76.2 \%(\mathrm{~N}=228) \\
\mathrm{F}: \mathrm{NI} \\
\text { Brushing } 7 \text { days a week at } \\
\text { bedtime: } \\
\text { B: } 34.4 \%(\mathrm{~N}=103) \\
\mathrm{F}: \mathrm{NI}\end{array}$ & $\begin{array}{l}0.700^{b} \\
0.860^{b} \\
0.830^{b}\end{array}$ \\
\hline & $\begin{array}{l}\text { Lopez-Jornet et al }{ }^{22} \\
\text { (2012) }\end{array}$ & $\begin{array}{c}\text { Brushing } 2 x \text { or more per } \\
\text { day: } \\
\text { B: } 53.3 \%(\mathrm{~N}=16) \\
\text { F: } 90.0 \%(\mathrm{~N}=27) \\
\text { Brushing duration } \geq 2 \text { min: } \\
\text { B: } 30.0 \%(\mathrm{~N}=9) \\
\text { F: } 70.0 \%(\mathrm{~N}=21) \\
\text { Interproximal tooth } \\
\text { brushing } 1 \mathrm{x} \text { day: } \\
\text { B: } 36.6 \%(\mathrm{~N}=11) \\
\text { F: } 59.9 \%(\mathrm{~N}=18)\end{array}$ & $\begin{array}{c}\text { Brushing } 2 \times \text { or more per } \\
\text { day: } \\
\text { B: } 86.6 \%(\mathrm{~N}=26) \\
\text { F: } 100.0 \%(\mathrm{~N}=30) \\
\text { Brushing duration } \geq 2 \text { min: } \\
\text { B: } 13.3 \%(\mathrm{~N}=4) \\
\text { F: } 80.0 \%(\mathrm{~N}=24) \\
\text { Interproximal tooth } \\
\text { brushing } 1 \mathrm{x} \text { day: } \\
\text { B: } 19.7 \%(\mathrm{~N}=6) \\
\text { F: } 56.6 \%(\mathrm{~N}=17)\end{array}$ & $\begin{array}{l}0.037^{\mathrm{a}} \\
0.038^{\mathrm{a}} \\
0.260^{\mathrm{a}}\end{array}$ \\
\hline Fluoride application ${ }^{c}$ & $\begin{array}{l}\text { Harisson et al }{ }^{15} \\
\qquad(2007)\end{array}$ & $\begin{array}{c}\text { B: mean } 0.0 \\
F: \text { mean } 0.25(S D 0.5)\end{array}$ & $\begin{array}{c}\text { B: mean } 0.0 \\
\text { F: mean } 3.81(S D 1.2)\end{array}$ & $0.001^{\mathrm{b}}$ \\
\hline \multicolumn{5}{|c|}{ Oral health clinical outcomes } \\
\hline Dental caries & $\begin{array}{l}\text { Harisson et al }{ }^{15} \\
(2007)\end{array}$ & $\begin{array}{c}\text { dmfs: } \\
\text { B: mean almost } 0.0(2 \\
\text { children) } \\
\text { F: mean } 7.59 \text { (SD 14.2) } \\
\text { dmfs plus noncavitated } \\
\text { lesions: } \\
\text { B: mean almost } 0.0(2 \\
\text { children) } \\
\text { F: mean } 7.91 \text { (SD 14.2) }\end{array}$ & $\begin{array}{c}\text { dmfs: } \\
\text { B: mean dmfs almost } 0.0(4 \\
\text { children) } \\
\text { F: mean dmfs } 3.35 \text { (SD 7.8) } \\
\text { dmfs plus noncavitated } \\
\text { lesions: } \\
\text { B: mean dmfs almost } 0.0(4 \\
\text { children) } \\
\text { F: mean } 3.52 \text { (SD 8.0) }\end{array}$ & $\begin{array}{l}0.001^{\mathrm{b}} \\
0.01^{\mathrm{b}}\end{array}$ \\
\hline & $\begin{array}{l}\text { Harisson et al }{ }^{16} \\
\qquad(2012)\end{array}$ & $\begin{array}{l}\text { Total incidence: } \\
\text { B: } \mathrm{NI} \\
\text { F: } 76.4 \%(\mathrm{~N}=100)\end{array}$ & $\begin{array}{c}\text { Total incidence: } \\
\mathrm{B}: \mathrm{NI} \\
\text { F: } 65.4 \%(\mathrm{~N}=72)\end{array}$ & $0.17^{b}$ \\
\hline & Ismail et al ${ }^{18}(2011)$ & $\begin{array}{l}\text { Cavitated and noncavitated } \\
\text { caries: } \\
\text { B: mean of } 5.59 \\
\text { F: incidence of } 6.4\end{array}$ & $\begin{array}{c}\text { Cavitated and noncavitated } \\
\text { caries: } \\
\text { B: } 5.65 \\
\text { F: incidence of } 6.5\end{array}$ & $0.990^{\mathrm{b}}$ \\
\hline \multirow[t]{3}{*}{ Dental plaque } & $\begin{array}{l}\text { Almomani et } \mathrm{al}^{1} \\
\underset{(2009)}{ }\end{array}$ & $\begin{array}{l}\text { B: mean } 3.3(\mathrm{SD} 0.8) \\
\mathrm{F}: \text { mean } 2.5(\mathrm{SD} 0.9)\end{array}$ & $\begin{array}{l}\text { B: mean } 3.6(\mathrm{SD} 0.6) \\
\text { F: mean } 1.9(\mathrm{SD} 0.7)\end{array}$ & $\mathrm{NI}$ \\
\hline & Brand et $\mathrm{al}^{6}(2012)$ & $\begin{array}{l}\text { B: mean } 2.6(\mathrm{SD} 0.5) \\
\text { F: mean } 2.3(\mathrm{SD} 0.7)\end{array}$ & $\begin{array}{l}\text { B: mean } 2.4(\mathrm{SD} 0.6) \\
\text { F: mean 2.1 (SD 2.1) }\end{array}$ & $0.390^{\mathrm{b}}$ \\
\hline & $\begin{array}{l}\text { Godard et al }{ }^{14} \\
\quad(2011)\end{array}$ & $\begin{array}{c}\text { B: mean } 58.0 \% \text { of sites (SD } \\
12 \text { ) } \\
\text { F: mean } 54.0 \% \text { of sites (SD } \\
12)\end{array}$ & $\begin{array}{c}\text { B: mean } 55.0 \% \text { of sites (SD } \\
15 \text { ) } \\
\text { F: mean } 34.0 \% \text { of sites (SD } \\
20 \text { ) }\end{array}$ & $0.01^{\mathrm{b}}$ \\
\hline
\end{tabular}


Continuation

\begin{tabular}{|c|c|c|c|c|}
\hline \multirow[t]{3}{*}{ Dental plaque } & $\begin{array}{c}\text { Lopez-Jornet et al }{ }^{22} \\
(2012)\end{array}$ & $\begin{array}{l}\text { B: mean } 0.4(S D 0.2) \\
\text { F: mean } 0.2(S D ~ 0.1)\end{array}$ & $\begin{array}{l}\text { B: mean } 0.7 \text { (SD 0.1) } \\
\text { F: mean } 0.3(S D 0.2)\end{array}$ & $\mathrm{NI}$ \\
\hline & $\begin{array}{l}\text { Jonsson et al }{ }^{19} \\
\qquad(2010)\end{array}$ & $\begin{array}{c}\text { B: mean } 57.0 \% \text { of sites (SD } \\
17 \text { ) } \\
\text { F: mean } 28.0 \% \text { of sites (SD } \\
13 \text { ) }\end{array}$ & $\begin{array}{c}\text { B: mean } 59.0 \% \text { of sites (SD } \\
18 \text { ) } \\
\text { F: mean } 14.0 \% \text { of sites (SD } \\
12)\end{array}$ & $<0.001^{\mathrm{b}}$ \\
\hline & $\begin{array}{c}\text { Stemann et al }{ }^{40} \\
(2013)\end{array}$ & $\begin{array}{c}\text { B: mean } 43.1 \% \text { of sites (SD } \\
19.2 \text { ) } \\
\text { F: mean } 18.6 \% \text { of sites (SD } \\
13.2 \text { ) }\end{array}$ & $\begin{array}{c}\text { B: mean } 50.2 \% \text { of sites (SD } \\
21.5) \\
\text { F: mean } 25.2 \% \text { of sites (SD } \\
15.4)\end{array}$ & $>0.05^{\mathrm{b}}$ \\
\hline \multirow[t]{4}{*}{ Bleeding on probing } & Brand et $\mathrm{al}^{6}(2012)$ & $\begin{array}{c}\text { B: mean } 55.0 \% \text { of sites (SD } \\
18) \\
\text { F: mean } 36.0 \% \text { of sites (SD } \\
20)\end{array}$ & $\begin{array}{c}\text { B: mean } 50.0 \% \text { of sites (SD } \\
18) \\
\text { F: mean } 33.0 \% \text { of sites (SD } \\
15)\end{array}$ & $0.263^{b}$ \\
\hline & $\begin{array}{l}\text { Lopez-Jornet et al }{ }^{22} \\
\qquad(2012)\end{array}$ & $\begin{array}{c}\text { B: mean } 22.4 \% \text { of sites (SD } \\
34.7) \\
\text { F: mean } 6.1 \% \text { of sites (SD } \\
13.4)\end{array}$ & $\begin{array}{c}\text { B: mean } 29.7 \% \text { of sites (SD } \\
34.9 \text { ) } \\
\text { F: mean } 18.4 \% \text { of sites (SD } \\
25.8)\end{array}$ & $\mathrm{NI}$ \\
\hline & $\begin{array}{l}\text { Jonsson et al }{ }^{19} \\
\qquad(2010)\end{array}$ & $\begin{array}{c}\text { B: mean } 75.0 \% \text { of sites (SD } \\
18 \text { ) } \\
\text { F: mean } 29.0 \% \text { of sites (SD } \\
14 \text { ) }\end{array}$ & $\begin{array}{c}\text { B: mean } 70.0 \% \text { of sites (SD } \\
20 \text { ) } \\
\text { F: mean } 19.0 \% \text { of sites(SD } \\
13 \text { ) }\end{array}$ & $<0.001^{b}$ \\
\hline & $\begin{array}{c}\text { Stemann et } \mathrm{al}^{40} \\
(2013)\end{array}$ & $\begin{array}{c}\text { B: mean } 33.0 \% \text { of sites (SD } \\
12.4) \\
\text { F: mean } 18.4 \% \text { of sites (SD } \\
14.1 \text { ) }\end{array}$ & $\begin{array}{c}\text { B: mean } 36.6 \% \text { of sites (SD } \\
17.1) \\
\text { F: mean } 18.8 \% \text { of sites (SD } \\
10.9)\end{array}$ & $>0.05^{\mathrm{b}}$ \\
\hline \multirow[t]{3}{*}{ Periodontal probing depth } & Brand et al ${ }^{6}(2012)$ & $\begin{array}{c}\text { PPD } 4-6 \mathrm{~mm} \text { : } \\
\text { B: mean } 23.3 \% \text { of sites (SD } \\
23.1 \text { ) } \\
\text { F: mean } 16.1 \% \text { of sites (SD } \\
21.4) \\
\text { PPD }>7 \mathrm{~mm} \text { : } \\
\text { B: mean } 1.8 \% \text { of sites (SD } \\
6.9 \text { ) } \\
\text { F: mean } 1.4 \% \text { of sites (SD } \\
5.7 \text { ) }\end{array}$ & $\begin{array}{c}\text { PPD } 4-6 \mathrm{~mm} \text { : } \\
\text { B: mean } 23.8 \% \text { of sites (SD } \\
15.8) \\
\text { F: mean } 20.3 \% \text { of sites (SD } \\
15.0) \\
\text { PPD }>7 \mathrm{~mm}: \\
\text { B: mean } 2.0 \% \text { of sites (SD } \\
4.1 \text { ) } \\
\text { F: mean } 1.7 \% \text { of sites (SD } \\
3.9 \text { ) }\end{array}$ & $\begin{array}{l}0.777^{b} \\
0.844^{b}\end{array}$ \\
\hline & $\begin{array}{l}\text { Jonsson et al }{ }^{19} \\
\qquad(2010)\end{array}$ & $\begin{array}{c}\text { PPD } 4-5 \mathrm{~mm} \text { : } \\
\text { B: mean } 33.0 \% \text { of sites (SD } \\
14.0 \text { ) } \\
\text { F: mean } 12.2 \% \text { of sites (SD } \\
10.8) \\
\text { PPD } \geq 6 \mathrm{~mm} \text { : } \\
\text { B: mean } 9.3 \% \text { of sites (SD } \\
11.0 \text { ) } \\
\text { F: mean } 1.5 \% \text { of sites (SD } \\
3.2 \text { ) }\end{array}$ & $\begin{array}{c}\text { PPD } 4-5 \mathrm{~mm} \text { : } \\
\text { B: mean } 31.0 \% \text { of sites (SD } \\
14.3) \\
\text { F: mean } 10.4 \% \text { of sites (SD } \\
7.9) \\
\text { PPD } \geq 6 \mathrm{~mm}: \\
\text { B: mean } 9.2 \% \text { of sites (SD } \\
9.3 \text { ) } \\
\text { F: mean } 1.6 \% \text { of sites (SD } \\
2.9 \text { ) }\end{array}$ & $\begin{array}{l}>0.05^{\mathrm{b}} \\
>0.05^{\mathrm{b}}\end{array}$ \\
\hline & $\begin{array}{l}\text { Lopez-Jornet et al }{ }^{22} \\
\qquad(2012)\end{array}$ & $\begin{array}{c}\text { PPD } 4-5 \mathrm{~mm}: \\
\text { B: mean } 1.7(\mathrm{SD} 7.5) \\
\text { F: mean } 1.5(\mathrm{SD} 7.1) \\
\text { PPD } \geq 6 \mathrm{~mm}: \\
\text { B: mean } 0.0 \\
\text { F: mean } 0.0\end{array}$ & $\begin{array}{c}\text { PPD 4-5 mm: } \\
\text { B: mean 3.5 (SD 9.5) } \\
\text { F: mean 2.6 (SD 7.1) } \\
\text { PPD } \geq 6 \text { mm: } \\
\text { B: mean 0.8 (SD 4.5) } \\
\text { F: mean 1.0 (SD 5.6) }\end{array}$ & $\begin{array}{l}\mathrm{NI} \\
\mathrm{NI}\end{array}$ \\
\hline
\end{tabular}

NI: not informed or not possible to calculate. B: baseline. F: final follow-up. PPD: periodontal pocket.

a Estimated p-value.

${ }^{\mathrm{b}}$ Informed by original authors.

c The application of fluoride varnishes provided was considered a proxy of oral health behavior on dental visits. 


\section{Periodontal conditions (gingival bleeding and periodontal pocket)}

There was limited evidence about the effectiveness of MI on periodontal pocket and gingival bleeding reduction. One study found significant effect of MI intervention at reducing gingival bleeding, showing a reduction of $73.0 \%$ in the intervention group compared to $62.0 \%$ in the control. Similar results on periodontal pockets reduction were showed for intervention and control groups, and no significant effects were found.

\section{DISCUSSION}

The overall quality of evidence of the studies was considered fair and the effect of the MI-based interventions on the outcomes assessed is not clear, since results were conflicting. Positive results were reported in four studies with lower quality of evidence ${ }^{14,15,19,22}$ while null effects were reported in another four studies with better quality evidence assessment. , $^{6,16,18,40}$

The target populations in the interventions differed considerably, making it hard to make comparisons between the studies or to compile evidence. It is not possible to assess what intensity of MI intervention is effective. The strongest evidence was found for the prevention of dental caries, provided by interventions with population-based samples. The largest study ${ }^{18}$ was the one that used the shortest schedule for the motivational interviews, two with each individual, compared to seven in the study where a significant positive effect was reported. ${ }^{15}$

The studies which assessed dental caries as an outcome reported its increment (number of new carious lesions, teeth or surfaces occurring in an individual within a stated period of time - DMFS index) by subtracting their caries experience score at baseline from their corresponding score at follow-up. Slade et al (1999) discussed several limitations of this analytical approach and presented a uniform alternative for enumerating caries events that permits DMFS increment to be applied both to cumulative and incidence density calculations. ${ }^{38}$ This analytic method addresses multiple events of caries initiation, progression and reversal, which may occur at different intervals on a single tooth surface.

The lack of uniformity in case definitions of periodontitis and the use of different theories and models for periodontal disease progression limit the assessment of the disease in longitudinal studies. ${ }^{5}$ The interventions included in this review used periodontal probing depth as a proxy of periodontal disease. However, the use of combinations of periodontal disease indicators are suggested under the rationale that they represent both cumulative tissue destruction (attachment loss) and current pathology (periodontal pocket depth). ${ }^{5}$
Evidence about reduction of dental plaque is unclear. However, where a significant effect was detected, the magnitude of reduction was large. Evidence on gingival bleeding and periodontal probing depth were also limited. We still need better studies with longer-term assessments to arrive at any firm conclusion.

Half of the studies presented an attempt to assess fidelity of the implementation to the original protocol, $, 1,6,15,18,40$ but only Ismail et $\mathrm{l}^{18}$ (2011) and Stemann et $\mathrm{al}^{40}$ (2012) presented a clearly defined strategy to measure fidelity. Fidelity assessment should take into account all key elements considered essential intervention components, and also non-specific elements, such as therapeutic alliance or empathy. These assessments are essential to understanding the effects on the outcomes., ${ }^{9,27}$

This was the largest review to examine the effectiveness of MI on oral health outcomes. Two independent reviewers assessed all publications identified by an extensive search of the literature performed in many databases and with no language limitations to avoid bias selection. Agreement between the reviewers was high, and a third reviewer resolved all discrepancies. All included articles were assessed by two independent reviewers in order to summarize the quality of evidence both global and for each outcome.

We were unable to summarize quantitative assessments of the included articles due to heterogeneity of the studies. The low number of publications and diversity of outcome measurements further hampered interpretation of the available evidence.

Based on the assessment of quality of the 10 articles, we suggest a few key points that should be considered for new interventions. It is essential that a sequence of endpoints, relevant to the assessment of effect on oral health, be assessed. They should include measures of knowledge and behavior, as well as clinical indicators with enough follow-up to capture the changes. Oral disease progression is influenced by several prognostic factors, such as age, sex, surfaces and tooth types, severity/activity of disease at baseline, socioeconomic level, oral health behaviors, among others, that should be considered in determining appropriate time of follow-up in order to assess significant changes. Sample size, individual selection and randomization procedure need to be carefully considered. The selection of individuals and the randomization process need to assure comparability of the groups. Special attention should be given to blinding clinical raters to intervention status of individuals and also to including appropriate process evaluation, by assessing whether the implementation of the proposed intervention was done according to protocol (fidelity).

The studies that showed beneficial effects conducted the interventions in clinical settings, applying MI 
individually. The only study performed with a larger sample in the community did not find any effect. ${ }^{18}$ Individual models for health prevention alone may not be enough to achieve sustainable improvements in health at a population level. ${ }^{4,32,42}$ As MI was developed to promote individual changes in a clinical setting, further research should answer whether effective interventions at the individual level are translatable to a public health scale.

\section{REFERENCES}

1. Almomani F, Williams K, Catley D, Brown C. Effects of an oral health promotion program in people with mental illness. J Dent Res. 2009;88(7):648-52. DOI: $10.1177 / 0022034509338156$

2. Attin T, Hornecker E. Tooth brushing and oral health: how frequently and when should tooth brushing be performed? Oral Health Prev Dent. 2005;3(3):135-40.

3. Baban A, Craciun C. Changing health-risk behaviors: a review of theory and evidence-based interventions in health psychology. J Cogn Behav Psychother. 2007;7(1):45-67.

4. Batchelor PA, Sheiham A. The distribution of burden of dental caries in schoolchildren: a critique of the high-risk caries prevention strategy for populations. BMC Oral Health. 2006;6:3. DOI:http://dx.doi.org/10.1186/1472-6831-6-3

5. Borrell LN, Papapanou PN. Analytical epidemiology of periodontitis. / Clin Periodontol. 2005;32(Suppl 6):132-58. DOI:10.1111/j.1600-051X.2005.00799.x

6. Brand VS, Bray KK, MacNeill S, Catley D, Williams K. Impact of single-session motivational interviewing on clinical outcomes following periodontal maintenance therapy. Int / Dent Hyg. 2013;11(2):134-41. DOI:10.1111/idh.12012

7. Brown LF. Research in dental health education and health promotion: a review of the literature. Health Educ Q. 1994;21(1):83-102. DOI:10.1177/109019819402100109

8. Burke BL, Arkowitz H, Menchola M. The efficacy of motivational interviewing: a meta-analysis of controlled clinical trials. J Consult Clin Psychol. 2003;71(5):843-61. DOI:10.1037/0022-006X.71.5.843

9. Campbell BK. Fidelity in public health clinical trials: considering provider-participant relationship factors in community treatment settings. J Public Health Dent. 2011;71 Suppl 1:64-5. DOI:10.1111/j.1752-7325.2011.00227.x

10. Carey KB, Scott-Sheldon LA, Carey MP, DeMartini KS. Individual-level interventions to reduce college student drinking: a meta-analytic review. Addict Behav. 2007;32(11):2469-94. DOI: 10.1016/S0306-4603(07)00145-1

11. Davies RM, Davies GM, Ellwood RP. Prevention. Part 4: Toothbrushing: what advice should be given to patients? Br Dent J. 2003;195(3):135-41. DOI:10.1038/sj.bdj.4810396
MI appears to be a promising approach for changing individual behavior in many health outcomes, ${ }^{10,17,24,33}$ and this is probably also true for oral health. The evidence we presented in this review is limited, but do allow us to be optimistic. The effectiveness of MI in changing oral health behavior and preventing dental diseases, such as caries and periodontal disease, is still unclear. We need more and better designed and reported interventions to fully assess its impact on oral health and longer term outcomes.

12. Downs SH, Black N. The feasibility of creating a checklist for the assessment of the methodological quality both of randomised and non-randomised studies of health care interventions. J Epidemiol Community Health. 1998;52(6):377-84. DOI:10.1136/jech.52.6.377

13. Freudenthal JJ, Bowen DM. Motivational interviewing to decrease parental risk-related behaviors for early childhood caries. J Dent Hyg. 2010;84(1):29-34.

14. Godard A, Dufour T, Jeanne S. Application of selfregulation theory and motivational interview for improving oral hygiene: a randomized controlled trial. J Clin Periodontol. 2011;38(12):1099-105. DOI:10.1111/j.1600-051X.2011.01782.x

15. Harrison R, Benton T, Everson-Stewart $S$, Weinstein P. Effect of motivational interviewing on rates of early childhood caries: a randomized trial. Pediatr Dent. 2007;29(1):16-22.

16. Harrison RL, Veronneau J, Leroux B. Effectiveness of maternal counseling in reducing caries in Cree children. J Dent Res. 2012;91(11):1032-7. DOI: $10.1177 / 0022034512459758$

17. Heckman CJ, Egleston BL, Hofmann MT. Efficacy of motivational interviewing for smoking cessation: a systematic review and meta-analysis. Tob Control. 2010;19(5):410-6. DOI:10.1136/tc.2009.033175

18. Ismail AI, Ondersma S, Jedele JM, Little RJ, Lepkowski JM. Evaluation of a brief tailored motivational intervention to prevent early childhood caries. Community Dent Oral Epidemiol. 2011;39(5):433-48. DOI:10.1111/j.1600-0528.2011.00613.x

19. Jonsson B, Ohrn K, Lindberg P, Oscarson N. Evaluation of an individually tailored oral health educational programme on periodontal health. J Clin Periodontol. 2010;37(10):912-9. DOI:10.1111/j.1600-051X.2010.01590.x

20. Jonsson B, Ohrn K, Oscarson N, Lindberg P. An individually tailored treatment programme for improved oral hygiene: introduction of a new course of action in health education for patients with periodontitis. Int J Dent Hyg. 2009;7(3):166-75. DOI:10.1111/j.1601-5037.2008.00350.x

21. Kay EJ, Locker D Is dental health education effective? A systematic review of current evidence. Community Dent Oral Epidemiol. 1996;24(4):231-5. DOI:10.1111/j.1600-0528.1996.tb00850.x 
22. Lopez-Jornet $\mathrm{P}$, Fabio CA, Consuelo RA, Paz AM. Effectiveness of a motivational-behavioural skills protocol for oral hygiene among patients with hyposalivation. Gerodontology. 2013. DOI:10.1111/ger.12037

23. Macdonald P, Hibbs R, Corfield F, Treasure J. The use of motivational interviewing in eating disorders: a systematic review. Psychiatry Res. 2012;200(1):1-11. DOI: 10.1016/S0165-1781(12)00263-6

24. Martins RK, McNeil DW. Review of Motivational Interviewing in promoting health behaviors. Clin Psychol Rev. 2009;29(4):283-93.

DOI: 10.1016/S0272-7358(09)00009-9

25. Miller RW, Rollnick S. Motivational Interviewing: Preparing People for Change. New York: Guilford Press; 2002.

26. Miller WR. A small study of training in motivational interviewing: does one workshop change clinician and client behavior? Behav Cogn Psychother. 2001;29(4):457-71. DOI:10.1017/S1352465801004064

27. Miller WR, Rose GS. Toward a theory of motivational interviewing. Am Psychol. 2009;64(6):527-37. DOI:10.1037/a0016830

28. Parlani S, Tripathi A, Singh SV. Increasing the prosthodontic awareness of an aging Indian rural population. Indian J Dent Res. 2011;22(3):367-70. DOI:10.4103/0970-9290.87054

29. Petersen PE. The World Oral Health Report 2003: continuous improvement of oral health in the $21 \mathrm{st}$ century--the approach of the WHO Global Oral Health Programme. Community Dent Oral Epidemiol. 2003;31 Suppl1:3-23. DOI:10.1046/j..2003.com122.x

30. Petersen PE. World Health Organization global policy for improvement of oral health--World Health Assembly 2007. Int Dent J. 2008;58(3):115-21.

31. Rollnick S, Kinnersley P, Stott N. Methods of helping patients with behaviour change. BMJ. 1993;307(6897):188-90. DOI:10.1136/bmj.307.6897.188

32. Rose G. Sick individuals and sick populations. Int J Epidemiol. 2001;30(3):427-32. DOI:10.1093/ije/14.1.32

33. Rubak S, Sandbaek A, Lauritzen T, Christensen B. Motivational interviewing: a systematic review and meta-analysis. Br J Gen Pract. 2005;55(513):305-12.
34. Sham AS, Cheung LK, Jin LJ, Corbet EF. The effects of tobacco use on oral health. Hong Kong Med J. 2003;9(4):271-7.

35. Shamani S, Jansson L. Oral hygiene behaviour change during the nonsurgical periodontal treatment phase. Open Dent J. 2012;6:190-6. DOI:10.2174/1874210601206010190

36. Sheiham A. Dietary effects on dental diseases. Public Health Nutr. 2001;4(2B):569-91. DOI:10.1079/PHN2001142

37. Skaret E, Weinstein P, Kvale G, Raadal M. An intervention program to reduce dental avoidance behaviour among adolescents: a pilot study. Eur J Paediatr Dent. 2003;4(4):191-6.

38. Slade GD, Caplan DJ. Methodological issues in longitudinal epidemiologic studies of dental caries. Community Dent Oral Epidemiol. 1999;27(4):236-48.

39. Sprod A, Andreson R, Treasure E. Effective oral health promotion: literature review. Health Promotion Wales. Cardiff, University of Wales; 1996.

40. Stenman J, Lundgren J, Wennstrom JL, Ericsson JS, Abrahamsson $\mathrm{KH}$. A single session of motivational interviewing as an additive means to improve adherence in periodontal infection control: a randomized controlled trial. J Clin Periodontol. 2012;39(10):947-54. DOI:10.1111/j.1600-051X.2012.01926.x

41. Twetman S. Prevention of early childhood caries (ECC) - review of literature published 19982007. Eur Arch Paediatr Dent. 2008;9(1):12-8. DOI:10.1007/BF03321590

42. Watt RG. Strategies and approaches in oral disease prevention and health promotion. Bull World Health Organ. 2005;83(9):711-8. DOI: S0042-96862005000900018

43. Weinstein P, Harrison R, Benton T. Motivating parents to prevent caries in their young children: one-year findings. J Am Dent Assoc. 2004;135(6):731-8. DOI:10.14219/jada.archive.2004.0299

44. Weinstein P, Harrison R, Benton T. Motivating mothers to prevent caries: confirming the beneficial effect of counseling. J Am Dent Assoc. 2006;137(6):789-93. DOI:10.14219/jada.archive.2006.0291

45. Yeung CA. Motivational interviewing in an oral health promotion programme. Evid Based Dent. 2010;11(1):14-5. DOI:10.1038/sj.ebd.6400703

Article based on doctoral thesis of Cascaes AM, entitled: "Desenho de uma intervenção para promoção da saúde bucal de famílias e crianças em idade pré-escolar: abordagem multi-métodos", presented to the Universidade Federal de Pelotas, in 2010.

The authors declare that there are no conflicts of interest. 